Review

\title{
New Perspectives on Oxidized Genome Damage and Repair Inhibition by Pro-Oxidant Metals in Neurological Diseases
}

\author{
Joy Mitra ${ }^{1,2, \dagger}$, Erika N. Guerrero ${ }^{1,3,4, \dagger}$, Pavana M. Hegde ${ }^{1}$, Haibo Wang ${ }^{1,2}$, Istvan Boldogh ${ }^{5}$,
} Kosagi Sharaf Rao ${ }^{3}$, Sankar Mitra ${ }^{1}$ and Muralidhar L. Hegde ${ }^{1,2, *}$

1 Department of Radiation Oncology, Houston Methodist Research Institute, Affiliate of Weill Medical College of Cornell University, 6550 Fannin St, Smith 8-030, Houston, TX 77030, USA; E-Mails: jmitra@houstonmethodist.org (J.M.); enguerrero@houstonmethodist.org (E.N.G.); pdixit@HoustonMethodist.org (P.M.H.); hwang@houstonmethodist.org (H.W.); smitra2@houstonmethodist.org (S.M.)

2 Houston Methodist Neurological Institute, Houston, TX 77030, USA

3 Centre for Neuroscience, Institute for Scientific Research and Technology Services (INDICASAT-AIP), City of Knowledge, P.O. Box 0843-01103, Panama; E-Mail: kjr5n2009@gmail.com

4 Department of Biotechnology, Acharya Nagarjuna University, Nagarjuna Nagar, Guntur 522510, India

5 Department of Microbiology and Immunology, University of Texas Medical Branch, Galveston, TX 77555, USA; E-Mail: sboldogh@utmb.edu

$\dagger$ These authors contributed equally to this work.

* Author to whom correspondence should be addressed; E-Mail: mlhegde@ houstonmethodist.org; Tel.: +1-713-441-7456; Fax: +1-713-790-3755.

Received: 29 April 2014; in revised form: 24 June 2014 / Accepted: 25 June 2014 /

Published: 17 July 2014

\begin{abstract}
The primary cause(s) of neuronal death in most cases of neurodegenerative diseases, including Alzheimer's and Parkinson's disease, are still unknown. However, the association of certain etiological factors, e.g., oxidative stress, protein misfolding/aggregation, redox metal accumulation and various types of damage to the genome, to pathological changes in the affected brain region(s) have been consistently observed. While redox metal toxicity received major attention in the last decade, its potential as a therapeutic target is still at a cross-roads, mostly because of the lack of mechanistic understanding of metal dyshomeostasis in affected neurons. Furthermore, previous studies have established the role of metals in causing genome damage, both directly and via the generation of reactive
\end{abstract}


oxygen species (ROS), but little was known about their impact on genome repair. Our recent studies demonstrated that excess levels of iron and copper observed in neurodegenerative disease-affected brain neurons could not only induce genome damage in neurons, but also affect their repair by oxidatively inhibiting NEIL DNA glycosylases, which initiate the repair of oxidized DNA bases. The inhibitory effect was reversed by a combination of metal chelators and reducing agents, which underscore the need for elucidating the molecular basis for the neuronal toxicity of metals in order to develop effective therapeutic approaches. In this review, we have focused on the oxidative genome damage repair pathway as a potential target for reducing pro-oxidant metal toxicity in neurological diseases.

Keywords: redox transition metals; heavy metals; DNA base excision repair; metal toxicity; metal homeostasis; neurodegeneration; Alzheimer's disease; Parkinson's disease

\section{Introduction}

Metal ions, many of which are essential in trace amounts, were also the first toxins known to humans. Even the essential metals are toxic or could be fatal when present in excess. A common mechanism of toxicity caused by redox-active metals is via the generation of reactive oxygen species (ROS), which affect both DNA and proteins.

While metals have been implicated in multiple pathologies, including cancer, neurotoxicity is believed to be their most common manifestation. Compelling evidence has etiologically linked abnormal brain metal accumulations with aging, as well as various neurological disorders, including Alzheimer's disease (AD), Parkinson's disease (PD), amyotrophic lateral sclerosis (ALS), Wilson's disease (WD) and stroke [1-4]. Furthermore, only a fraction of these metal-accumulation diseases can be sourced to dietary or occupational exposure [1,5-7], although the source, as well as precise mechanism(s) of the majority of metal accumulation conditions remain obscure. It is important to mention that unlike other toxic compounds, the increased metal ion level could impact the homeostasis of all metals in the cell or organ due to its charged state and the natural cellular response towards maintaining a tight charge balance. In spite of an extensive literature on individual metal toxicity, the impact of metal dyshomeostasis is not completely understood.

Because of extensive genome damage observed in metal-associated diseases, a casual linkage was suggested between excessive cellular metal levels and genotoxicity. Subsequent studies established the role of heavy metals, such as lead $(\mathrm{Pb})$, chromium $(\mathrm{Cr})$, nickel $(\mathrm{Ni})$, etc., in causing direct damage to DNA via cross-linking and interference with transcription and replication processes, enhancing mutagenesis. Other metals, including cadmium $(\mathrm{Cd})$ and copper $(\mathrm{Cu})$, were shown to hinder cell growth and promote apoptosis [8], although, the underlying mechanism is not clear.

Interestingly, recent studies have implicated a reduced genome damage repair capacity in neurons of individuals afflicted with metal-accumulating neurodegenerative diseases [9-11], implicating the accumulation of pro-oxidant metals in enhanced levels of unrepaired oxidative DNA damage. This prompted us and other investigators to examine the effect of metals on DNA repair pathways and 
to understand the interplay among these diverse etiologies in neuronal toxicity. Redox-active $\mathrm{Cu}$ and iron $(\mathrm{Fe})$ not only induce genome damage, but also specifically inhibit key enzymes in the oxidative genome damage machinery by both altering their structure and reversibly oxidizing cysteine residues in these proteins. We propose that inhibition of DNA repair plays a critical role in affecting the survival of postmitotic neurons, with inherently limited capacity for genome maintenance, because of the absence of replication-coupled repair processes. Furthermore, the reversible nature of metals' inhibitory effect on DNA repair could be exploited to restore repair using specific metal chelators with reducing activity. These studies, which were subsequently corroborated by others, provided a new paradigm in our understanding of metal genotoxicity in neurons. In this review, we discuss the current knowledge on DNA repair pathways in neurons, the role of both essential and toxic metals in blocking these processes and how the mechanistic understanding of the phenomenon could be exploited for efficient therapeutic interventions.

\section{Oxidative Insults and Repair in Human Genome}

Oxidative genome damage is an inevitable consequence of metabolism in aerobic organisms. ROS and reactive nitrogen species (RNS) are continuously produced during respiration [12] and also during the activation of cellular defense pathways [13]. The levels of these pro-oxidants, including free radicals, can be enhanced several fold upon exposure to external factors, like heavy metals, smoking, ionizing radiation and other genotoxic stress [14-16]. A balance between DNA damage and repair capacity exists in a healthy cell to efficiently repair an estimated $10^{4}$ oxidized base lesions and single-strand breaks (SSBs) that are generated by ROS daily in a mammalian cell's genome $[17,18]$. In addition to ROS and RNS, accumulated transition metals (e.g., $\mathrm{Fe}, \mathrm{Cu}, \mathrm{Cr}, \mathrm{Cd}$ and cobalt (Co)), most of which are redox-active, induce a plethora of toxic free radicals through their participation in various cellular oxidation-reduction reactions. In the presence of hydrogen peroxide, these $\mathrm{Fe}$ and $\mathrm{Cu}$ ions generate toxic hydroxyl radicals via a Fenton or Fenton-like reactions $[19,20]$, as illustrated below.

$$
\begin{gathered}
\mathrm{Fe}(\mathrm{III})+\mathrm{O}_{2}^{\bullet-} \leftrightarrow \mathrm{Fe}(\mathrm{II})+\mathrm{O}_{2} \\
\mathrm{Fe}(\mathrm{II})+\mathrm{H}_{2} \mathrm{O}_{2} \rightarrow \mathrm{Fe}(\mathrm{III})+\mathrm{OH}^{\bullet}+\mathrm{OH}^{-} \text {(Fenton reaction) } \\
\mathrm{Cu}(\mathrm{I})+\mathrm{H}_{2} \mathrm{O}_{2} \rightarrow \mathrm{Cu}(\mathrm{II})+\mathrm{OH}^{\bullet}+\mathrm{OH}^{-}
\end{gathered}
$$

In addition, hydroxyl free radicals are also generated as a product of the Haber-Weiss reaction [21].

$$
\begin{aligned}
& \mathrm{O}_{2}^{\bullet-}+\mathrm{H}_{2} \mathrm{O}_{2} \leftrightarrow \mathrm{O}_{2}+\mathrm{OH}^{\bullet}+\mathrm{OH}^{-} \\
& \mathrm{OH}^{\bullet}+\mathrm{H}_{2} \mathrm{O}_{2} \rightarrow \mathrm{H}_{2} \mathrm{O}+\mathrm{H}^{+}+\mathrm{O}_{2}^{\bullet-}
\end{aligned}
$$

\subsection{Types of Oxidative Damage in DNA}

Several dozens of oxidized base modifications, apurinic/apyrimidinic (AP) lesions, oxidized sugar fragments and SSBs with various blocked termini (Table 1) are induced by ROS in the human genome [22,23]. These, when unrepaired, have been implicated in various pathophysiological conditions. Common base lesions 5-hydroxyuracil (5-OHU), thymine glycol, 8-oxo-7,8-dihydroguanine (8-oxoG), 2,6-diamino-4-hydroxy-5-formamidopyrimidine (Fapy-G) and 4,6-diamino-5-formamidopyrimidine (Fapy-A) have been identified in affected regions of the AD brain (Figure 1) [24,25]. Sugar oxidation 
normally causes SSB formation in DNA [26,27], which is also formed as an intermediate during the repair of oxidized base lesions. The common ROS-induced SSBs include 3'-phosphoglycolate, 3'-phosphate and 5'-deoxyribosephosphate blocked termini, whose processing is a critical step in the repair pathway $[28,29]$.

Table 1. Human diseases associated with metal toxicity. While excessive metal ions have been linked to genomic instability in cancer, the major manifestation of metal toxicity is aging and age-related neurological diseases, implying the susceptibility of the CNS.

\begin{tabular}{ccc}
\hline Disease & Linked Metal Toxicity & References \\
\hline Alzheimer's Disease & $\mathrm{Fe}, \mathrm{Cu}, \mathrm{Zn}, \mathrm{Al}$ & {$[30-34]$} \\
Parkinson's Disease & $\mathrm{Fe}, \mathrm{Zn}, \mathrm{Al}, \mathrm{Cu}, \mathrm{Mn}$ & {$[1,10,34-40]$} \\
Huntington's Disease & $\mathrm{Cu}, \mathrm{Fe}$ & {$[41-47]$} \\
Wilson's Disease & $\mathrm{Cu}, \mathrm{Fe}$ & {$[48-51]$} \\
Amyotrophic Lateral Sclerosis & $\mathrm{Fe}, \mathrm{Cu}$ & {$[52,53]$} \\
Friedreich's Ataxia & $\mathrm{Fe}, \mathrm{Cu}, \mathrm{Zn}$ & {$[54-56]$} \\
Xeroderma Pigmentosum & $\mathrm{Co}, \mathrm{Cd}, \mathrm{Ni}$ & {$[57-59]$} \\
Cancer & $\mathrm{Fe}, \mathrm{Pb}, \mathrm{Cd}, \mathrm{Ni}, \mathrm{Hg}, \mathrm{Co}$ & {$[20,60-65]$} \\
\hline
\end{tabular}

Figure 1. ROS and RNS are constantly produced during aerobic metabolism. ROS generate several dozen oxidized base lesions and single-strand breaks (SSBs) in the genome. SSBs are also generated as intermediates during the processing of oxidized bases via base excision repair (BER). ROS-induced SSBs contain diverse termini, like 3'-phosphoglycolate, 3'-phosphate, 5'-OH and 5'-deoxyribose phosphate.

ROS/NOS and other free radicals

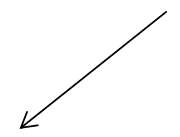

Oxidized base lesion

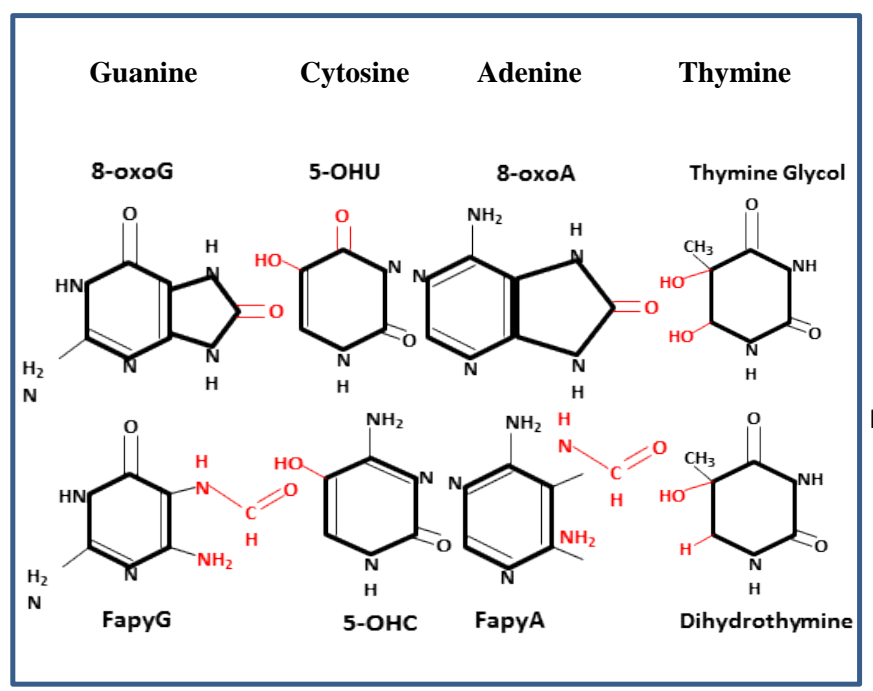

SSB

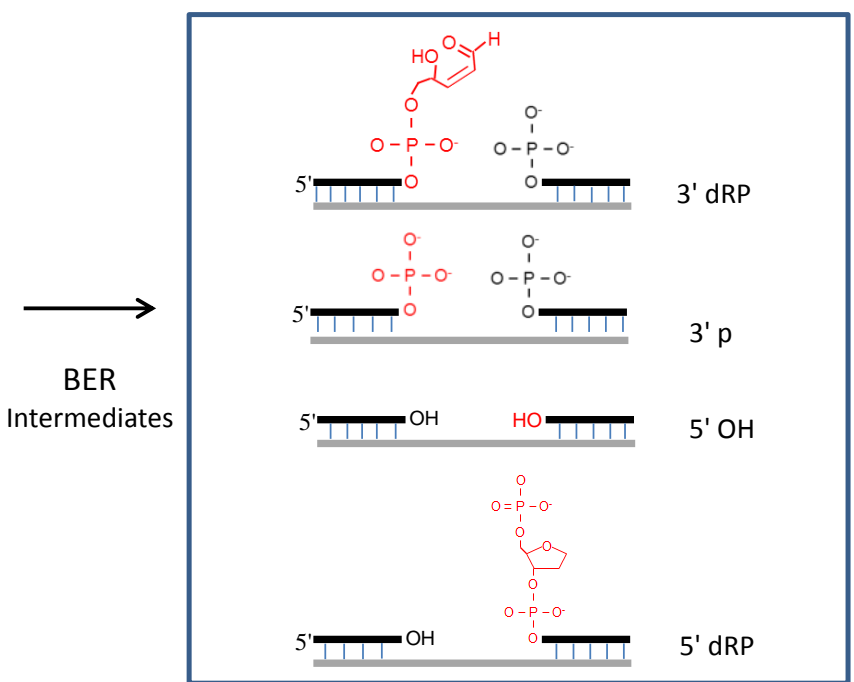




\subsection{Repair of Oxidative Genome Damage: Basic Mechanism(s) and Complexity}

Most oxidized damage in the genome, including base lesions, AP sites and SSBs, are repaired via the base excision/single-strand break repair (BER/SSBR) pathway, which is highly versatile and evolutionarily conserved from bacteria to humans. In its simplistic form, BER involves four key reactions, namely: (i) recognition and excision of the base lesion by a DNA glycosylase and cleavage of the resulting AP site by the glycosylase itself (for oxidized base-specific bi-functional enzymes) in a sequential reaction or by AP endonuclease 1 (APE1) (for mono-functional glycosylases) in the following step; (ii) processing of the $5^{\prime}$ and/or $3^{\prime}$ blocked termini by specific SSB end cleaning enzymes to generate polymerase-compatible 5'-P/3'-OH ends; (iii) nucleotide gap filling by a DNA polymerase; and finally, (iv) DNA ligases (Lig III or I) seal the resulting nick to complete the repair process.

Oxidized base-specific DNA glycosylases, discovered so far in humans, belong to two families, namely Nth and Nei. 8-oxoguanine DNA glycosylase-1 (OGG1) and NTH1 in the Nth family prefer oxidized purines and pyrimidines, respectively, from duplex DNA [66]. Recently discovered NEIL1 and NEIL2, belonging to the Nei group [67-69], mostly prefer oxidized pyrimidine, both in duplex and single-stranded DNA, with a weaker activity with some purine lesions [70,71]. Recently characterized NEIL3, the fifth member of the Nei family [72], was shown to remove a broad spectrum of base lesions on single-stranded DNA with a preference for spiroiminodihydantoin (Sp) and guanidinohydantoin (Gh), which are the subsequent oxidation products of 8-oxoG [73,74]. Two types of 3'-non-ligatable termini are generated during the processing of oxidized bases by these glycosylases. OGG1 and NTH1 execute a $\beta$ lyase reaction at the AP site yielding 3 '-phospho- $\alpha, \beta$-unsaturated aldehyde (3'-dRP) and 5'-P; on the other hand, NEILs catalyze $\beta \delta$ elimination, forming 3'-P and 5'-P groups [75]. APE1 and polynucleotide kinase 3'-phosphatase (PNKP) work downstream of glycosylases in the BER pathway, removing 3'-dRP and 3'-P, respectively. However, APE1 primarily processes AP sites generated by mono-functional glycosylases to produce strand breaks with 3'-OH and 5'-dRP ends. In mammalian cells, Pol $\beta$ acts as a bi-functional enzyme, possessing both polymerase and 5'-dRP lyase activity, removing the dRP residue to generate 5'-OH terminus [76], in addition to incorporating the missing nucleotide at the $3^{\prime}-\mathrm{OH}$. While Pol $\beta$ predominantly participates in single nucleotide incorporation or short patch (SP- or SN-) BER, replicative DNA polymerase $\delta(\mathrm{Pol} \delta$ )-mediated BER was identified to involve a repair patch size of 2-8 nucleotides in a long patch (LP) BER pathway. Flap endonuclease 1 (FEN-1) is required for such repair to cleave off the displaced flap structure $[77,78]$. Furthermore, although few studies have suggested the ability of Pol $\beta$ to participate in LP-BER in vitro, in coordination with FEN-1, whether it occurs in vivo is unclear [79]. In the final repair step, LigI or LigIII $\alpha$ complete the nick sealing process of the phosphodiester backbone. LigI primarily acts during DNA replication and during LP-BER [23,80]. Recently, LigIII was shown to be redundant for nuclear DNA repair, because LigI serves as proficient back up [81]. The LigI expression level is highest in proliferating cells and reduced levels are present in non-cycling cells, like neurons, indicating that LigIII cannot substitute for all of the LigI-related activities [82]. A unique feature of the mammalian $\mathrm{BER} / \mathrm{SSBR}$ is that the interactions of the BER proteins are highly coordinated and play a crucial role in efficient repair [78,83]. 


\subsection{SSBR, a Variant of BER with Diverse End-Processing Reactions}

ROS-induced SSBs could involve several types of non-ligatable termini, in addition to the ones observed in BER, and thus, SSBR employs additional end-processing enzymes [23]. 3'-phosphoglycolate and 3'-phosphoglycolaldehyde in mammalian genomes are generally removed by APE1. Tyrosyl phosphodiesterase I (TDP1) cleaves tyrosine-linked 3'-P generated by abortive topoisomerase I (Top I) reaction to 3 '-P at the strand break in the TDP1/DNA complex [84,85]. Here, PNKP plays a dual role by both processing 3'-P and adding phosphate to the 5'-OH end [86]. Aprataxin releases 5'-AMP to restore the 5'-P terminus [87,88]. Some 3'-non-ligatable termini could also be excised by the XRCC1/XPF nuclease complex, which has an essential role in the nucleotide excision repair (NER) pathway by incising the damage-containing DNA strand 3' to the lesion site. After the conventional 3'-OH/5'-P are generated, SSBR and BER follow the same gap filling and ligation reactions. Thus, although end processing is more diverse in SSBR than BER, they share the last two reaction steps and enzymes.

\subsection{Complexity of BER/SSBR Pathway}

Unlike in bacteria, BER/SSBR in human cells is highly complex, involving additional cellular proteins that regulate the cell cycle dependence of repair, genome region-specific repair sub-pathways and in several back-up pathways [77,89]. These include accessary proteins XRCC1, PARP-1 and -2, and non-canonical proteins hnRNP-U, YB1, etc. [23,75,89-97]. Furthermore, post-translational modifications in one or more components, including acetylation [98-101], phosphorylation [102-104], ubiquitylation [105-107], SUMOylation [108-110], methylation [111,112] and PARylation [113-115], regulate the repair process and rate in various cellular states. While a detailed account of specific modifications in BER/SSBR machinery is beyond the scope of this review, recent studies linking defects in acetylases/deacetylases with dramatic BER/SSBR deficiency and mutagenicity highlight the importance of such modifications in repair [101,116,117].

The presence of non-conserved, mostly disordered terminal peptide segments in early BER/SSBR proteins, as comprehensively reviewed in our previous review [23,118], could be critical for key functions, including damage sensing, protein-protein interactions, repair regulation via posttranslational modifications and nuclear localization signal (NLS) [118]. We believe that mammalian early BER enzymes, like NEIL1 or APE1, could be considered as "hub" proteins with multiple interacting partners $(>10)$, most of which utilize terminal disordered segment as common interaction interface [23,118,119].

\subsection{Mitochondrial (Mt) BER/SSBR}

MtDNA is highly susceptible to oxidative stress because of its close proximity to the site of ROS generation and lack of protective histones [120,121]. The proteins involved in mtBER are encoded by the nuclear genome, many of which are identical to their nuclear counterparts, but few distinct mitochondrial specific isoforms exist. LigIII exists in distinct nuclear and mitochondrial isoforms, but only nuclear LigIII $\alpha$ works in complex with the scaffold protein, XRCC1, in vivo $[80,122]$. Mitochondria have only one DNA polymerase (Pol $\gamma$ ), which participates in both mtDNA replication and repair [123]. The high lipid content of mitochondrial membranes facilitates the accumulation of alkylating agents [124] and cationic metals, such as $\mathrm{Cd}$, mercury $(\mathrm{Hg}), \mathrm{Pb}$, manganese $(\mathrm{Mn}), \mathrm{Fe}$ and 
$\mathrm{Cu}$ [125-127]. Furthermore, as would be expected, a higher mitochondrial BER capacity is observed in brain than other tissue types [128,129].

\section{Current Understanding of BER/SSBR in the Central Nervous System (CNS)}

The CNS consists of the brain and spinal cord with multiple cell types, including neuron and glial cells. The major bottleneck for DNA repair in neuronal cells is that these cells are terminally differentiated and lack replication-associated repair [4]. Regulation of BER in neurons in various pathophysiological conditions is largely unknown [130]. During neuronal maturation, a decreased OGG1 level and increased NEIL1 and NEIL2 levels have been observed in rat brain [131]. It has been suggested that both NEIL1 and NEIL2 might have a potential role in maintaining the integrity of transcribed genes in terminally differentiated neurons. Studies demonstrating impaired memory retention in mice lacking NEIL1 further support the critical role of this enzyme in brain cells [132]. Besides protecting the genome from the accumulation of cytotoxic base lesions, the distribution and activity of NEIL3 in brain direct its specific role in stem cell differentiation [133,134]. NEIL3 is required for maintaining DNA integrity in neural progenitor cells, both during development and in adult brain [135]. NEIL $3^{-/-}$mice showed memory defects, coupled with the impaired proliferative capacity of hippocampal neural stem/progenitor cells, which is also correlated to reduced DNA repair capacity. Further, NEIL3-deficient neural progenitor cells were highly susceptible to oxidative stress [136]. Another glycosylase, specific for alkylated bases, MPG expresses strongly in cerebral cortex, cerebellum and hippocampus in brain [137]. Although, OGG1's activity was found to be low in brain, NTH1 showed comparable expression and activity in brain, testes, kidney and liver. There are conflicting reports on brain OGG1 levels in ageing and neurological disorders: while a decreased OGG1 activity was observed in aged rat brain [138], its level was shown to increase in substantia nigra in PD [139]. Interestingly, a recent study suggested 8-oxoG repair via MUTYH-mediated BER (MUTYH excises A mispaired with 8-oxoG) rather than OGG1-mediated BER of the 8-oxoG-C pair. Consistently, mice lacking MUTYH were resistant to neurodegeneration, while mice lacking OGG1 or MTH1 (an enzyme that depletes 8-oxoGTP from the pool) exhibited severe striatal neurodegeneration [140]. These findings suggest that MUTYH-mediated 8-oxoG repair may promote neurodegeneration. Both PNKP and APE1 are highly expressed in brain. The neuroprotective role of APE1 in the survival of oxidative stress-induced post-mitotic neurons has been well established [141-143]. The interaction of PNKP with scaffold protein XRCC1 has been shown to be crucial for efficient BER processing during oxidative stress [144]. Pol $\beta$, the major DNA polymerase in non-cycling neurons, is ubiquitously expressed in all brain regions [145], and its level decreases in an age-dependent manner. Other DNA replication-associated repair proteins', like FEN-1, Pol $\delta / \varepsilon$, PCNA and LigI, levels have been observed to be low in the adult brain, as expected, while XRCC1 and LigIII levels are high with respect to other tissue types [146]. These studies indicate that SN-BER might be the major BER pathway with a reduced level of LP-BER in matured neurons [147,148]. 


\section{Revisiting Metal Toxicity Diseases}

\subsection{Metal Accumulation in CNS Etiologically Linked to Neurological Diseases}

Metals, such as Fe, Zn, Cu, Se, Mn, Mo, Co, Na and K, and other elements, like S, P, I, F, etc., are indispensable for life, because of their essential role in fundamental life functions. These are beneficial at a lower (optimum) concentration, but are toxic at a higher concentration. Most metals enter the brain through the "blood brain barrier" (BBB) using specific carrier proteins.

While the metal content is tightly regulated in normal brain, by being sequestered with storage proteins, e.g., ferritin, transferrin and ceruloplasmin, and released only in response to metabolic need, metal dyshomeostasis leading to the abnormal overload of free metal ions is a common feature in the pathogenesis of most, if not all, neurodegenerative diseases and aging. Specifically, accumulations of $\mathrm{Fe}, \mathrm{Cu}, \mathrm{Al}, \mathrm{Mn}$, etc. (either individually or together), is implicated in AD, PD, ALS, hereditary ferritinopathy and WD [48,149-153].

\subsubsection{Essential Transition Metals}

$\mathrm{Fe}, \mathrm{Cu}$ and $\mathrm{Zn}$ : The redox states of $\mathrm{Fe}(\mathrm{II} / \mathrm{III})$ and $\mathrm{Cu}(\mathrm{I} / \mathrm{II})$ that make them biologically important also make them toxic, due to the production of ROS. While most of the Fe in a healthy human body is present in hemoglobin, along with $\mathrm{Cu}$ and $\mathrm{Zn}$, it serves as essential co-factors for a multitude of enzymes and signaling molecules and, thus, regulates various biological pathways, including mitochondrial energy production, DNA replication/transcription, synthesis of neurotransmitters, etc. In the normal brain, the major fraction of bio-available $\mathrm{Fe}$ and $\mathrm{Cu}(\sim 70 \%)$ are typically sequestered in ferritin/transferrin and ceruloplasmin, respectively [154,155]. Studies have implicated $\mathrm{Cu}, \mathrm{Fe}$ and $\mathrm{Zn}$ as key factors in the pathophysiology of $\mathrm{AD}$ and PD [156,157]. High levels of $\mathrm{Cu}(400 \mu \mathrm{M})$ and $\mathrm{Zn}$ $(1 \mathrm{mM})$ were found in amyloid plaques and $\mathrm{AD}$ neuropil regions in comparison to healthy brain (70 $\mu \mathrm{M} \mathrm{Cu}$ and $350 \mu \mathrm{M} \mathrm{Zn)} \mathrm{[32,158],} \mathrm{which} \mathrm{accumulate} \mathrm{progressively} \mathrm{during} \mathrm{the} \mathrm{transition} \mathrm{from}$ moderate to severe $\mathrm{AD}$ [156]. Furthermore, the injection of $\mathrm{FeCl}_{3}$ into the substantia nigra of adult rats resulted in a substantial selective decrease of striatal dopamine (95\%), leading to PD-like symptoms [159]. $\mathrm{Mn}$ is another essential transition metal, ubiquitous in human cells in trace levels, primarily acting as a cofactor of mitochondria-specific SOD. Exposure of mice to a high Mn level causes a clinical disease characterized by extrapyramidal symptom resembling idiopathic PD (IPD) [160]. Further, the ability of $\mathrm{Mn}$ to enhance $\alpha$-synuclein and amyloid- $\beta$ misfolding/aggregation coupled with its abnormal distribution in brain suggests that Mn toxicity could contribute to AD, Huntington disease and ALS.

\subsubsection{Non-Essential Heavy Metals' Impact on Human Health}

$\mathrm{Al}$, an abundant element in the environment, is used in industry, medicine, food, water processing and agriculture. The average uptake of $\mathrm{Al}$ (III) ranges from 2.5 to $13 \mathrm{mg} / \mathrm{day}$, depending on the food and cooking practice of country. Although, consistently implicated in the pathogenesis of $\mathrm{AD}$, for the better part of the last century, the definite etiology of Al toxicity in AD has remained unknown. Al has never been demonstrated to have any definite biological function, but many studies have brought to 
light its potential neurotoxicity in experimental animal models and in humans [161-163]. A detailed role of $\mathrm{Al}$ in neurodegenerative diseases was reviewed elsewhere [164].

$\mathrm{Pb}$ and $\mathrm{Hg}: \mathrm{Pb}(\mathrm{II} / \mathrm{IV})$ is a well-known neurotoxicant in children. The predominant route of exposure is through the ingestion of contaminated food, although Pd-based paint and contaminated water also contribute. $\mathrm{Pb}$ exposure has been linked with reduced IQ and behavior in children. It is considered to be a risk factor in accelerated cognitive decline, AD and PD [165]. Rodent studies suggest a reduction in the number of dopamine neurons and significant alterations in the nigrostriatal dopamine system after being exposed to $\mathrm{Pb}$, which is consistent with $\mathrm{PD}$ pathology [166]. $\mathrm{Pb}$ also increases the expression of APP mRNA and elevated amyloid beta aggregation [167]. Primates exposed to $\mathrm{Pb}$ showed increased amyloidogenesis and senile plaque formation, both studies consistent with what is observed in AD brain samples [168].

$\mathrm{Hg}$, another heavy metal, is highly neurotoxic, particularly when converted into methyl-Hg. This, commonly ingested via contaminated fish, passes through the BBB by binding to cysteine. $\mathrm{Hg}$ (II) exposure in humans causes PD-like pathology, including movement dysfunction, tremors and polyneuropathy. Mice exposed to methyl-Hg exhibit reduced neuritis of dopaminergic neurons and a reduction of striatal dopamine [169]. Finally, $\mathrm{Hg}$ and $\mathrm{Pb}$ could also generate $\mathrm{ROS}$ via lipid peroxidation, mitochondrial damage and superoxide production [170].

\subsection{Complex Nature of Metal Toxicity in Neurodegenerative Diseases}

\subsubsection{Environmental/Occupational Exposure versus Internal Redistribution}

While occupational or environmental exposure to metals predisposes humans to neurological dysfunction, as expected, these constitute only a small fraction of human neurodegenerative diseases. The majority of patients showing a marked increase in the levels of various metals in brain have no known metal exposure or increased dietary intake. Interestingly, we demonstrated that metal levels in blood and brain are inversely correlated in AD and PD [171,172], indicating metal redistribution from blood to brain or CSF, but the mechanism is unclear. We proposed that such an increased metal uptake in the brain may be driven by a toxic misfolded (amyloid) protein response. Most metals promote amyloid protein aggregation. This makes the highly toxic misfolded amyloid proteins inert initially, but when the aggregate level increases beyond a cells' threshold, it would aggravate the neurotoxicity.

\subsubsection{Transition Metals' Charge-Dependent Changes with Disease Progression}

Remarkably, studies also revealed that transition metals in their divalent states (e.g., $\mathrm{Fe}(\mathrm{II})$ or $\mathrm{Cu}(\mathrm{II})$ ) increase in the early phase of $\mathrm{AD}$, while trivalent forms (Fe(III) tend to increase in the later phase of the AD-affected brain [172]. Furthermore, an increase in trivalent metals forms in late-stage $\mathrm{AD}$ is accompanied with decrease in mono- or di-valent metals. Thus, the overall brain metal burden is never dramatically increased in AD; instead there is the abnormal redistribution of specific metals in different organs. In general, it appears that a common trait in many processes underlying neurodegeneration is a (direct or indirect) perturbation in the homeostasis of $\mathrm{Cu}, \mathrm{Zn}, \mathrm{Fe}, \mathrm{Al}$, etc. This could be important for formulating metal chelation therapy, which should consider supplementing the depleted metal, in addition to chelating the increased metal ions. 


\subsection{Metal Toxicity as Homeostatic Imbalance: A New Perspective}

There is a limited database on trace metal homeostasis in brain. Although several reports are available on individual metal level changes/distribution, no studies have successfully correlated the inter-elemental relationships. Our limited previous studies provided new information on the metal-homeostasis pattern in the brain and serum samples of AD/PD patients $[1,173]$. Due to the tight regulation of charge balance in a cell and across the membrane, the effect of changes in the level of a particular metal is not restricted to that metal alone, but instead, it would impact many other metals in that particular organ and, eventually, lead to metal dyshomeostasis and cellular dysfunction. This information is novel, but needs substantial database development to compute a model reflecting the total trace elemental homeostasis in human brain. We feel that such a database will be of great significance, not only for the early diagnosis of neurodegenerative and neuro-psychiatric disorders, but also in understanding these disorders using elemental homeostasis as a model system. Although numerous hypotheses have been proposed for the involvement of metals in various neurological dysfunctions (reviewed in [7,174]), conclusive evidence still remains vague, presumably due to the complex and dynamic nature of metal levels and toxicity. Hence, there is a need for a methodology to map not only trace element levels, but also to establish metal-metal-dependent-interrelationships in human brain with relevance to progressive metal accumulation diseases.

\section{Metals Induce Genome Damage, Both Directly and Circuitously}

Metal toxicity-linked conditions, including most neurological disorders, are commonly associated with extensive genome damage, particularly oxidative base damage and strand breaks [175], which suggest a causal link between the two phenomenon. Redox cycling $\mathrm{Fe}$ and $\mathrm{Cu}$ generate ROS via the Fenton reaction producing hydroxyl and superoxide radicals that further damage DNA. These metals can also produce DNA damage by their directly binding and nicking activity [176]. Other heavy metals, like $\mathrm{Pb}, \mathrm{Cd}$, etc., and $\mathrm{Al}$ also indirectly promote ROS/RNS generation by their high affinity binding to thiol groups containing enzymes and proteins [177,178], which are responsible for normal cellular defense mechanism against oxidative stress. Furthermore, while ROS and/or metals induce various oxidative modifications in DNA bases and SSBs, the accumulation of closely-spaced SSBs in non-cycling neurons could lead to secondary DSBs, which are the most toxic type of DNA genome damage [179].

\section{Inhibition of DNA Repair by Redox Metals: A Double Whammy}

\subsection{Pro-Oxidant Metals Inhibit BER Pathways}

While a significant decrease in genome repair capacity, including BER in neurons, has been observed in neurodegenerative diseases, as well as during ageing [180-183], the molecular events leading to such deficiency have not been characterized. A lack of a direct correlation between repair deficiencies with the expression of repair enzymes suggests the involvement of additional mechanisms. Repair defects involving heavy metal exposure were attributed to direct DNA binding, which not only induce DNA strand breaks, but also interfere with damage scanning and the recruitment of repair 
machinery [184,185]. However, repair defects in most cases of sporadic neurodegenerative diseases that involve the dyshomeostasis of essential transition metals, such as $\mathrm{Cu}$ and $\mathrm{Fe}$, were not characterized until recently, when we demonstrated that $\mathrm{Cu}$ and Fe specifically inhibit the activities of NEIL1 and NEIL2 by forming stable complexes with these proteins [9]. We showed that $\mathrm{Fe}(\mathrm{II} / \mathrm{III})$ and $\mathrm{Cu}$ (II) at nanomolar $(\mathrm{nM})$ to low micromolar $(\mu \mathrm{M})$ levels inhibit NEILs' activity with various base lesion-containing DNA substrates in vitro. The inhibition was found to be very specific, as demonstrated by the lack of a similar inhibition of OGG1 with 8-oxoG substrates. This also suggested that in contrast to the previously suspected mechanism, the inhibition is due to metal binding to NEILs rather than to DNA. The binding involved both hydrophobic and electrostatic forces, as indicated by the large negative enthalpy. In cell inhibition of NEILs by these metals was also observed based on the reduced repair activity of NEILs in extracts from SH-SY5Y neuroblastoma cells treated with $\mathrm{FeSO}_{4} \mathrm{or} \mathrm{CuCl}_{2}$.

\subsection{Mechanism of Repair Inhibition: Oxidation of Cysteines in NEIL DNA Glycosylases}

Partial reversal of $\mathrm{Cu}$-mediated NEIL1 inhibition by a $\mathrm{Cu}$-chelator, but nearly complete reversal, by a combination of a $\mathrm{Cu}$-chelator, plus a reducing agent or curcumin with dual metal chelation, as well as reducing properties, suggested that NEIL1 inhibition by $\mathrm{Cu}$ involves the reversible oxidation of cysteine residues [9]. Furthermore, the CD spectra of the NEIL1-Cu complex showed a small, but clear, change in the secondary structure of NEIL1, which could cause the inhibition of its activity. Interestingly, although both $\mathrm{Cu}$ (II) and $\mathrm{Fe}$ (II) bind to NEIL1 and NEIL2, the secondary structure of NEIL2, unlike NEIL1, is not affected significantly. Given the presence of a zinc finger motif in NEIL2, but not in NEIL1, Cu(II) or Fe(II) may competitively replace the intrinsic Zn ion in NEIL2 and compromise its folding.

Further, metal ions also disrupt protein-protein interactions during BER. DNA damage repair involves a highly coordinated signaling pathway that depends on appropriate protein-protein interactions during the signal transduction. We showed that Fe(II) affects NEIL1's interaction with Pol $\beta$ and FEN-1, which is critical for overall BER [9]. Thus, unlike previous studies that suggested that the inhibition of BER repair by metals may be due to their direct binding to DNA, these studies demonstrate a direct binding of redox metals with specific BER proteins, which affect their structure, as well as activities.

\subsection{Summary of Metal Toxicity Impact on Other DNA Repair Enzymes/Pathways}

In addition to NEILs, metal ions also inhibit other components of the DNA repair machinery (Table 2). It was observed that $\sim 60 \%$ of LigIII $\alpha$ activity was inhibited by $\mathrm{FeCl}_{3}(10-250 \mu \mathrm{M})$, which also affects $\mathrm{Pol} \beta$ [11]. The divalent ions, $\mathrm{Cd}^{2+}, \mathrm{Ni}^{2+}$ and $\mathrm{Zn}^{2+}$, inhibit the activity of recombinant human $N$-methylpurine-DNA glycosylase (MPG), a monofunctional DNA glycosylase, which removes a variety of alkylated bases $[186,187]$. Whiteside et al. showed that $\mathrm{Cd}$ and $\mathrm{Cu}$ inhibit phosphatase and kinase activities of both recombinant PNKP and its activity in human cell extracts [188]. Heavy metals could delay SSB rejoining in mammalian cells. Further, elevated Fe levels caused a reduction in FEN-1 and LigIII activities, due to the interference of repair protein binding to their DNA substrates [9].

Thus, metal mediated genotoxicity could involve the induction of oxidative genome damage via: (i) free radical generation; and (ii) direct DNA binding; and inhibition of DNA repair via (i) inhibition of key BER/SSBR enzymes; and (ii) inhibiting interactions among repair proteins. Taken together, 
these studies showed that excessive $\mathrm{Fe} / \mathrm{Cu}$ and other pro-oxidant metals in neurodegenerative brains act as a "double whammy" by inducing ROS that damage the genome and also by inhibiting damage repair at the same time (Figure 2).

Table 2. Key genome repair enzymes affected by metals. Transition and heavy metals have been shown to inhibit the repair activities of key proteins involved in the BER, single-strand break repair (SSBR) and DSBR pathways.

\begin{tabular}{cccc}
\hline Repair Protein Affected by Metal(s) & Repair Pathway & Inhibiting Metal & References \\
\hline NEIL1 & BER & $\mathrm{Fe}, \mathrm{Cu}$ & {$[9,175]$} \\
NEIL2 & BER & $\mathrm{Fe}, \mathrm{Cu}$ & {$[9,175]$} \\
APE1 & BER/SSBR & $\mathrm{Fe}, \mathrm{Cd}, \mathrm{Pb}$ & {$[189]$} \\
PNKP & BER/SSBR/DSBR & $\mathrm{Cd}, \mathrm{Cu}$ & {$[188]$} \\
FEN-1 & BER/SSBR/DSBR & $\mathrm{Fe}$ & {$[11]$} \\
LigIII & BER/SSBR/DSBR & $\mathrm{Fe}$ & {$[11]$} \\
MPG & BER & $\mathrm{Cd}, \mathrm{Ni}, \mathrm{Zn}$ & {$[186,187]$} \\
\hline
\end{tabular}

Figure 2. The genotoxicity of metals in neuronal cells: a "double-whammy". Excess accumulation of metals in neurons not only causes increased oxidative damage to the genome, both directly and via ROS, but also inhibits the repair of such damage by binding/oxidizing certain repair proteins. This creates an imbalance between genome damage and repair, and the resulting persistent accumulation of damage contributes to neuronal dysfunction and cell death.

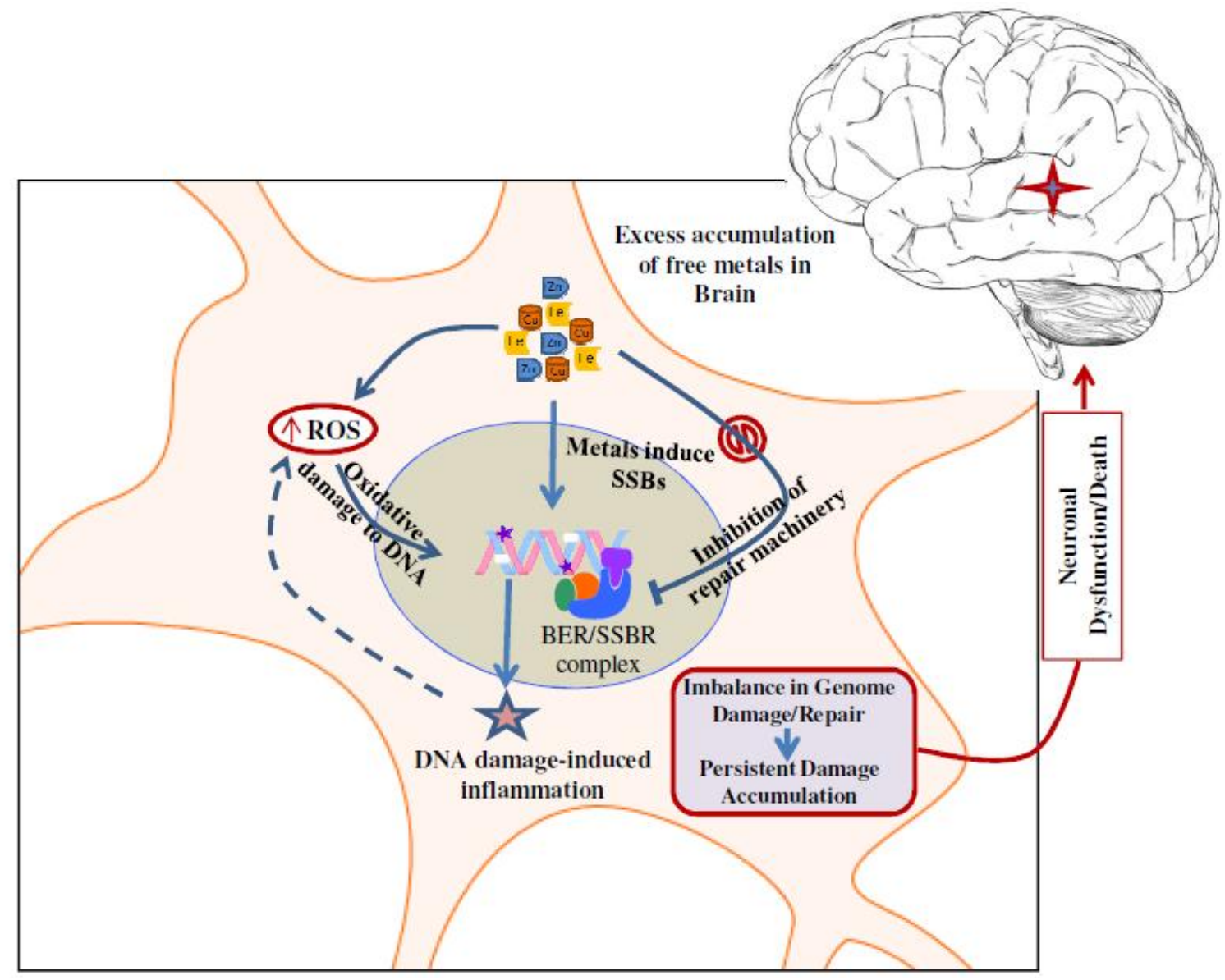




\section{Conclusions and Future Perspectives}

\section{Molecular Understanding of the Complex, Multi-Targeted Nature of Metal Toxicity Is Important for} Intervention Strategies

Despite an enormous increase in our understanding of the neuropathological events in aging and in 200 types of neurological conditions, there is no cure available; current treatments slow progressive dementia only temporarily. This underscores the necessity of an overarching approach to explore newer strategies to unravel the mechanism of initiation/progression of neurodegeneration and to find more effective ways to prevent its onset, delay the progression and then effectively treat the disease to improve the quality of life for patients and their caregivers. Furthermore, despite multiple studies providing compelling evidence linking the misfolding/oligomerization of $A \beta /$ tau, the build-up of $F e / C u$ and other metals, the accumulation of genomic damage in the brain, how the interplay among these factors triggers neuronal apoptosis is still unclear. The role of metals as the key mediators of AD pathology has been reinforced by the fact that metal-chelation therapy has turned out to be promising in animal models of $\mathrm{AD}$, although challenges regarding chelator choice and/or dosage together with the side effects of their sequestration of essential metals persist $[9,190]$. Our studies demonstrating that $\mathrm{Fe} / \mathrm{Cu}$ acts as a "double whammy" by inducing genome damage and also inhibiting its repair provided a molecular basis, whereby $\mathrm{Cu}$ reduces cysteine residues in NEILs, which could be reversed by a $\mathrm{Cu}$ chelator in combination with a reducing agent or curcumin, which has both chelating and reducing properties. In addition, other compounds/drugs, particularly of natural/plant origin with antioxidant/free radical scavenging, as well as metal chelation activities, should be looked into for their neuroprotective functions [191]. For example, melatonin, which possesses both antioxidant and metal chelation properties, has been demonstrated to reduce metal-induced toxicity in cells [192]. However, the protective role of melatonin in preventing metal-induced DNA repair inhibition still needs to be investigated. In view of melatonin's ability to stimulate antioxidant enzymes, in addition to free radical scavenging and metal chelation, it will be interesting to examine a combination of melatonin and curcumin for preventing multimodal metal toxicity conditions. These results suggested that it is important to comprehensively understand the metal levels in a given case; characterizing the complete metal homeostasis and specific toxicity of the metals involved, including their role in genome damage/repair systems is required in order to develop an effective therapy [191]. This underscores the need to re-examine the role of metal toxicity in neurological diseases as a part of a therapeutic strategy in light of the new information of the human genome and its functions.

\section{Acknowledgments}

The research in the authors' laboratories is supported by grants from the Alzheimer's Association (NIRG-12-12-242135; Muralidhar L. Hegde), the Muscular Dystrophy Association (MDA294842; Muralidhar L. Hegde), the Houston Methodist Research Institute (Muralidhar L. Hegde), USPHS (R01 CA158910 and P01 CA92584; Sankar Mitra; R01 ES018948 and R01 AI062885; Istvan Boldogh), the Melo Brain Grant (Muralidhar L. Hegde and Kosagi Sharaf Rao), and SNI of SENACYT-Panama for doctoral fellowship (Erika Guerrero). Erika Guerrero We thank Sanjay Adhikari, Shiladitya Sengupta, Chunying Yang and Arijit Dutta for various discussions. This review with a limited focus on 
the impact of metal toxicity on genome damage and repair is not intended to provide a comprehensive literature on the topic, and hence, many appropriate citations may not be included, for which we sincerely apologize.

\section{Author Contributions}

Joy Mitra and Erika Guerrero prepared the first draft of the manuscript with assistance from Pavana Hegde and Haibo Wang, who also contributed in preparing the specific sections. Istvan Boldogh, Kosagi Rao and Sankar Mitra provided expert insights and edited the manuscript. Muralidhar Hegde directed the project, and prepared the final manuscript.

\section{Conflicts of Interest}

The authors declare no conflict of interest.

\section{References}

1. Hegde, M.L.; Shanmugavelu, P.; Vengamma, B.; Rao, T.S.; Menon, R.B.; Rao, R.V.; Rao, K.S. Serum trace element levels and the complexity of inter-element relations in patients with parkinson's disease. J. Trace Elem. Med. Biol. 2004, 18, 163-171.

2. Faller, P.; Hureau, C.; Berthoumieu, O. Role of metal ions in the self-assembly of the Alzheimer's amyloid-beta peptide. Inorg. Chem. 2013, 52, 12193-12206.

3. Stork, C.J.; Li, Y.V. Rising zinc: A significant cause of ischemic neuronal death in the CA1 region of rat hippocampus. J. Cereb. Blood Flow Metab. 2009, 29, 1399-1408.

4. Hanawalt, P.C. Emerging links between premature ageing and defective DNA repair. Mech. Ageing Dev. 2008, 129, 503-505.

5. Tchounwou, P.B.; Yedjou, C.G., Patlolla, A.K.; Sutton, D.J. Heavy metal toxicity and the environment. Mol. Clin. Environ. Toxicol. 2012, 101, 133-164.

6. Hartmann, A.; Speit, G. Effect of arsenic and cadmium on the persistence of mutagen-induced DNA lesions in human cells. Environ. Mol. Mutagen. 1996, 27, 98-104.

7. Hegde, M.L.; Bharathi, P.; Suram, A.; Venugopal, C.; Jagannathan, R.; Poddar, P.; Srinivas, P.; Sambamurti, K.; Rao, K.J.; Scancar, J.; et al. Challenges associated with metal chelation therapy in Alzheimer's disease. J. Alzheimers Dis. 2009, 17, 457-468.

8. Kim, S.; Cheon, H.S.; Kim, S.Y.; Juhnn, Y.S.; Kim, Y.Y. Cadmium induces neuronal cell death through reactive oxygen species activated by GADD153. BMC Cell Biol. 2013, doi:10.1186/1471-2121-14-4.

9. Hegde, M.L.; Hegde, P.M.; Holthauzen, L.M.; Hazra, T.K.; Rao, K.S.; Mitra, S. Specific inhibition of NEIL-initiated repair of oxidized base damage in human genome by copper and iron: Potential etiological linkage to neurodegenerative diseases. J. Biol. Chem. 2010, 285, 28812-28825.

10. Zatta, P.; Lucchini, R.; van Rensburg, S.J.; Taylor, A. The role of metals in neurodegenerative processes: Aluminum, manganese, and zinc. Brain Res. Bull. 2003, 62, 15-28. 
11. Li, H.; Swiercz, R.; Englander, E.W. Elevated metals compromise repair of oxidative DNA damage via the base excision repair pathway: Implications of pathologic iron overload in the brain on integrity of neuronal DNA. J. Neurochem. 2009, 110, 1774-1783.

12. Breen, A.P.; Murphy, J.A. Reactions of oxyl radicals with DNA. Free Radic. Biol. Med. 1995, 18, 1033-1077.

13. Janssen, Y.M.; van Houten, B.; Borm, P.J.; Mossman, B.T. Cell and tissue responses to oxidative damage. Lab. Investig. 1993, 69, 261-274.

14. Church, D.F.; Pryor, W.A. Free-radical chemistry of cigarette smoke and its toxicological implications. Environ. Health Perspect. 1985, 64, 111-126.

15. Comhair, S.A.; Thomassen, M.J.; Erzurum, S.C. Differential induction of extracellular glutathione peroxidase and nitric oxide synthase 2 in airways of healthy individuals exposed to $100 \% \mathrm{O}_{2}$ or cigarette smoke. Am. J. Respir. Cell Mol. Biol. 2000, 23, 350-354.

16. Narayanan, P.K.; Goodwin, E.H.; Lehnert, B.E. Alpha particles initiate biological production of superoxide anions and hydrogen peroxide in human cells. Cancer Res. 1997, 57, 3963-3971.

17. Friedberg, E.C.; Walker, G.C.; Siede, W.; Wood, R.D.; Schultz, R.A.; Ellenberger, T. DNA Repair and Mutagenesis, 2nd ed.; ASM Press: Washington, DC, USA, 2006.

18. Pardo, B.; Gomez-Gonzalez, B.; Aguilera, A. DNA repair in mammalian cells: DNA double-strand break repair: How to fix a broken relationship. Cell. Mol. Life Sci. 2009, 66, 1039-1056.

19. Lloyd, R.V.; Hanna, P.M.; Mason, R.P. The origin of the hydroxyl radical oxygen in the fenton reaction. Free Radic. Biol. Med. 1997, 22, 885-888.

20. Toyokuni, S. Iron and carcinogenesis: From fenton reaction to target genes. Redox Rep. 2002, 7 , 189-197.

21. Valko, M.; Izakovic, M.; Mazur, M.; Rhodes, C.J.; Telser, J. Role of oxygen radicals in DNA damage and cancer incidence. Mol. Cell. Biochem. 2004, 266, 37-56.

22. Mitra, S.; Izumi, T.; Boldogh, I.; Bhakat, K.K.; Hill, J.W.; Hazra, T.K. Choreography of oxidative damage repair in mammalian genomes. Free Radic. Biol. Med. 2002, 33, 15-28.

23. Hegde, M.L.; Hazra, T.K.; Mitra, S. Early steps in the DNA base excision/single-strand interruption repair pathway in mammalian cells. Cell Res. 2008, 18, 27-47.

24. Lyras, L.; Cairns, N.J.; Jenner, A.; Jenner, P.; Halliwell, B. An assessment of oxidative damage to proteins, lipids, and DNA in brain from patients with Alzheimer's disease. J. Neurochem. 1997, 68, 2061-2069.

25. Halliwell, B. Antioxidant defence mechanisms: From the beginning to the end (of the beginning). Free Radic. Res. 1999, 31, 261-272.

26. Tsuzuki, K.; Sugiyama, M.; Haramaki, N. DNA single-strand breaks and cytotoxicity induced by chromate(VI), cadmium(II), and mercury(II) in hydrogen peroxide-resistant cell lines. Environ. Health Perspect. 1994, 102, 341-342.

27. Lai, H.; Singh, N.P. Magnetic-field-induced DNA strand breaks in brain cells of the rat. Environ. Health Perspect. 2004, 112, 687-694.

28. Chen, Q.; Marsh, J.; Ames, B.; Mossman, B. Detection of 8-oxo-2'-deoxyguanosine, a marker of oxidative DNA damage, in culture medium from human mesothelial cells exposed to crocidolite asbestos. Carcinogenesis 1996, 17, 2525-2527. 
29. Radak, Z.; Boldogh, I. 8-oxo-7,8-dihydroguanine: Links to gene expression, aging, and defense against oxidative stress. Free Radic. Biol. Med. 2010, 49, 587-596.

30. .Bourassa, M.W.; Leskovjan, A.C.; Tappero, R.V.; Farquhar, E.R.; Colton, C.A.; van Nostrand, W.E.; Miller, L.M. Elevated copper in the amyloid plaques and iron in the cortex are observed in mouse models of Alzheimer's disease that exhibit neurodegeneration. Biomed. Spectrosc. Imaging 2013, 2, 129-139.

31. Tiiman, A.; Palumaa, P.; Tougu, V. The missing link in the amyloid cascade of Alzheimer's disease-Metal ions. Neurochem. Int. 2013, 62, 367-378.

32. Lovell, M.A.; Robertson, J.D.; Teesdale, W.J.; Campbell, J.L.; Markesbery, W.R. Copper, iron and zinc in Alzheimer's disease senile plaques. J. Neurol. Sci. 1998, 158, 47-52.

33. Strong, M.J. Aluminum neurotoxicity: An experimental approach to the induction of neurofilamentous inclusions. J. Neurol. Sci. 1994, 124, 20-26.

34. Zecca, L.; Youdim, M.B.; Riederer, P.; Connor, J.R.; Crichton, R.R. Iron, brain ageing and neurodegenerative disorders. Nat. Rev. Neurosci. 2004, 5, 863-873.

35. Sofic, E.; Riederer, P.; Heinsen, H.; Beckmann, H.; Reynolds, G.P.; Hebenstreit, G.; Youdim, M.B. Increased iron (III) and total iron content in post mortem substantia nigra of parkinsonian brain. J. Neural. Transm. 1988, 74, 199-205.

36. Schipper, H.M. Astrocytes, brain aging, and neurodegeneration. Neurobiol. Aging 1996, 17, 467-480.

37. Forte, G.; Bocca, B.; Senofonte, O.; Petrucci, F.; Brusa, L.; Stanzione, P.; Zannino, S.; Violante, N.; Alimonti, A.; Sancesario, G. Trace and major elements in whole blood, serum, cerebrospinal fluid and urine of patients with Parkinson's disease. J. Neural. Transm. 2004, 111, 1031-1040.

38. Rasia, R.M.; Bertoncini, C.W.; Marsh, D.; Hoyer, W.; Cherny, D.; Zweckstetter, M.; Griesinger, C.; Jovin, T.M.; Fernandez, C.O. Structural characterization of copper(II) binding to alpha-synuclein: Insights into the bioinorganic chemistry of Parkinson's disease. Proc. Natl. Acad. Sci. USA 2005, 102, 4294-4299.

39. Lucchini, R.G.; Martin, C.J.; Doney, B.C. From manganism to manganese-induced parkinsonism: A conceptual model based on the evolution of exposure. Neuromol. Med. 2009, 11, 311-321.

40. Milatovic, D.; Zaja-Milatovic, S.; Gupta, R.C.; Yu, Y.; Aschner, M. Oxidative damage and neurodegeneration in manganese-induced neurotoxicity. Toxicol. Appl. Pharmacol. 2009, 240, 219-225.

41. Fox, J.H.; Kama, J.A.; Lieberman, G.; Chopra, R.; Dorsey, K.; Chopra, V.; Volitakis, I.; Cherny, R.A.; Bush, A.I.; Hersch, S. Mechanisms of copper ion mediated Huntington's disease progression. PLoS One 2007, 2, e334.

42. Xiao, B.G.; Link, H. Immune regulation within the central nervous system. J. Neurol. Sci. 1998, $157,1-12$.

43. Dexter, D.T.; Jenner, P.; Schapira, A.H.; Marsden, C.D. Alterations in levels of iron, ferritin, and other trace metals in neurodegenerative diseases affecting the basal ganglia. The royal kings and queens Parkinson's disease research group. Ann. Neurol. 1992, 32, S94-S100. 
44. Boll, M.C.; Alcaraz-Zubeldia, M.; Montes, S.; Rios, C. Free copper, ferroxidase and SOD1 activities, lipid peroxidation and $\mathrm{NO}_{\mathrm{x}}$ content in the CSF. A different marker profile in four neurodegenerative diseases. Neurochem. Res. 2008, 33, 1717-1723.

45. Loeffler, D.A.; LeWitt, P.A.; Juneau, P.L.; Sima, A.A.; Nguyen, H.U.; DeMaggio, A.J.; Brickman, C.M.; Brewer, G.J.; Dick, R.D.; Troyer, M.D.; et al. Increased regional brain concentrations of ceruloplasmin in neurodegenerative disorders. Brain Res. 1996, 738, 265-274.

46. Simmons, D.A.; Casale, M.; Alcon, B.; Pham, N.; Narayan, N.; Lynch, G. Ferritin accumulation in dystrophic microglia is an early event in the development of Huntington's disease. Glia 2007, 55, 1074-1084.

47. Bartzokis, G.; Cummings, J.; Perlman, S.; Hance, D.B.; Mintz, J. Increased basal ganglia iron levels in Huntington disease. Arch. Neurol. 1999, 56, 569-574.

48. Fatemi, N.; Sarkar, B. Molecular mechanism of copper transport in wilson disease. Environ. Health Perspect. 2002, 110, 695-698.

49. Litwin, T.; Gromadzka, G.; Szpak, G.M.; Jablonka-Salach, K.; Bulska, E.; Czlonkowska, A. Brain metal accumulation in Wilson's disease. J. Neurol. Sci. 2013, 329, 55-58.

50. DiDonato, M.; Hsu, H.F.; Narindrasorasak, S.; Que, L., Jr.; Sarkar, B. Copper-induced conformational changes in the N-terminal domain of the Wilson disease copper-transporting ATPase. Biochemistry 2000, 39, 1890-1896.

51. Kanwar, P.; Kowdley, K.V. Metal storage disorders: Wilson disease and hemochromatosis. Med. Clin. North Am. 2014, 98, 87-102.

52. Jeong, S.Y.; Rathore, K.I.; Schulz, K.; Ponka, P.; Arosio, P.; David, S. Dysregulation of iron homeostasis in the CNS contributes to disease progression in a mouse model of amyotrophic lateral sclerosis. J. Neurosci. 2009, 29, 610-619.

53. Kasarskis, E.J.; Tandon, L.; Lovell, M.A.; Ehmann, W.D. Aluminum, calcium, and iron in the spinal cord of patients with sporadic amyotrophic lateral sclerosis using laser microprobe mass spectroscopy: A preliminary study. J. Neurol. Sci. 1995, 130, 203-208.

54. Koeppen, A.H.; Ramirez, R.L.; Yu, D.; Collins, S.E.; Qian, J.; Parsons, P.J.; Yang, K.X.; Chen, Z.; Mazurkiewicz, J.E.; Feustel, P.J. Friedreich's ataxia causes redistribution of iron, copper, and zinc in the dentate nucleus. Cerebellum 2012, 11, 845-860.

55. Hu, K.H.; Friede, R.L. Topographic determination of zinc in human brain by atomic absorption spectrophotometry. J. Neurochem. 1968, 15, 677-685.

56. Cossee, M.; Puccio, H.; Gansmuller, A.; Koutnikova, H.; Dierich, A.; LeMeur, M.; Fischbeck, K.; Dolle, P.; Koenig, M. Inactivation of the friedreich ataxia mouse gene leads to early embryonic lethality without iron accumulation. Hum. Mol. Genet. 2000, 9, 1219-1226.

57. Kopera, E.; Schwerdtle, T.; Hartwig, A.; Bal, W. Co(II) and Cd(II) substitute for Zn(II) in the zinc finger derived from the DNA repair protein XPA, demonstrating a variety of potential mechanisms of toxicity. Chem. Res. Toxicol. 2004, 17, 1452-1458.

58. Hartwig, A.; Schwerdtle, T.; Bal, W. Biophysical analysis of the interaction of toxic metal ions and oxidants with the zinc finger domain of XPA. Methods Mol. Biol. 2010, 649, 399-410.

59. Bal, W.; Schwerdtle, T.; Hartwig, A. Mechanism of NICKEl assault on the zinc finger of DNA repair protein XPA. Chem. Res. Toxicol. 2003, 16, 242-248. 
60. Zhou, Z.; Wang, C.; Liu, H.; Huang, Q.; Wang, M.; Lei, Y. Cadmium induced cell apoptosis, DNA damage, decreased DNA repair capacity, and genomic instability during malignant transformation of human bronchial epithelial cells. Int. J. Med. Sci. 2013, 10, 1485-1496.

61. Smith, E.B. Primary cancer of the lung in women. J. Natl. Med. Assoc. 1989, 81, 945-948.

62. Lam, T.V.; Agovino, P.; Niu, X.; Roche, L. Linkage study of cancer risk among lead-exposed workers in new jersey. Sci. Total Environ. 2007, 372, 455-462.

63. Beveridge, R.; Pintos, J.; Parent, M.E.; Asselin, J.; Siemiatycki, J. Lung cancer risk associated with occupational exposure to NICKEl, chromium VI, and cadmium in two population-based case-control studies in montreal. Am. J. Ind. Med. 2010, 53, 476-485.

64. Koedrith, P.; Kim, H.; Weon, J.I.; Seo, Y.R. Toxicogenomic approaches for understanding molecular mechanisms of heavy metal mutagenicity and carcinogenicity. Int. J. Hyg. Environ. Health 2013, 216, 587-598.

65. Aquino, N.B.; Sevigny, M.B.; Sabangan, J.; Louie, M.C. The role of cadmium and NICKEl in estrogen receptor signaling and breast cancer: Metalloestrogens or not? J. Environ. Sci. Health C 2012, 30, 189-224.

66. McCullough, A.K.; Dodson, M.L.; Lloyd, R.S. Initiation of base excision repair: Glycosylase mechanisms and structures. Annu. Rev. Biochem. 1999, 68, 255-285.

67. Bandaru, V.; Sunkara, S.; Wallace, S.S.; Bond, J.P. A novel human DNA glycosylase that removes oxidative DNA damage and is homologous to Escherichia coli endonuclease VIII. DNA Repair 2002, 1, 517-529.

68. Hazra, T.K.; Izumi, T.; Boldogh, I.; Imhoff, B.; Kow, Y.W.; Jaruga, P.; Dizdaroglu, M.; Mitra, S. Identification and characterization of a human DNA glycosylase for repair of modified bases in oxidatively damaged DNA. Proc. Natl. Acad. Sci. USA 2002, 99, 3523-3528.

69. Ellenberger, T.; Tomkinson, A.E. Eukaryotic DNA ligases: Structural and functional insights. Annu. Rev. Biochem. 2008, 77, 313-338.

70. Prakash, A.; Doublie, S.; Wallace, S.S. The Fpg/Nei family of DNA glycosylases: Substrates, structures, and search for damage. Prog. Mol. Biol. Transl. Sci. 2012, 110, 71-91.

71. Hazra, T.K.; Kow, Y.W.; Hatahet, Z.; Imhoff, B.; Boldogh, I.; Mokkapati, S.K.; Mitra, S.; Izumi, T. Identification and characterization of a novel human DNA glycosylase for repair of cytosine-derived lesions. J. Biol. Chem. 2002, 277, 30417-30420.

72. Liu, M.; Bandaru, V.; Bond, J.P.; Jaruga, P.; Zhao, X.; Christov, P.P.; Burrows, C.J.; Rizzo, C.J.; Dizdaroglu, M.; Wallace, S.S. The mouse ortholog of NEIL3 is a functional DNA glycosylase in vitro and in vivo. Proc. Natl. Acad. Sci. USA 2010, 107, 4925-4930.

73. Wallace, S.S.; Bandaru, V.; Kathe, S.D.; Bond, J.P. The enigma of endonuclease VIII. DNA Repair 2003, 2, 441-453.

74. Wallace, S.S. Base excision repair: A critical player in many games. DNA Repair 2014, 19, 14-26.

75. Wiederhold, L.; Leppard, J.B.; Kedar, P.; Karimi-Busheri, F.; Rasouli-Nia, A.; Weinfeld, M.; Tomkinson, A.E.; Izumi, T.; Prasad, R.; Wilson, S.H.; et al. AP endonuclease-independent DNA base excision repair in human cells. Mol. Cell 2004, 15, 209-220.

76. Sobol, R.W.; Prasad, R.; Evenski, A.; Baker, A.; Yang, X.P.; Horton, J.K.; Wilson, S.H. The lyase activity of the DNA repair protein beta-polymerase protects from DNA-damage-induced cytotoxicity. Nature 2000, 405, 807-810. 
77. Hegde, M.L.; Hegde, P.M.; Bellot, L.J.; Mandal, S.M.; Hazra, T.K.; Li, G.M.; Boldogh, I.; Tomkinson, A.E.; Mitra, S. Prereplicative repair of oxidized bases in the human genome is mediated by neil1 DNA glycosylase together with replication proteins. Proc. Natl. Acad. Sci. USA 2013, 110, E3090-E3099.

78. Hegde, M.L.; Theriot, C.A.; Das, A.; Hegde, P.M.; Guo, Z.; Gary, R.K.; Hazra, T.K.; Shen, B.; Mitra, S. Physical and functional interaction between human oxidized base-specific DNA glycosylase NEIL1 and flap endonuclease 1. J. Biol. Chem. 2008, 283, 27028-27037.

79. Liu, Y.; Kao, H.I.; Bambara, R.A. Flap endonuclease 1: A central component of DNA metabolism. Annu. Rev. Biochem. 2004, 73, 589-615.

80. Tomkinson, A.E.; Chen, L.; Dong, Z.; Leppard, J.B.; Levin, D.S.; Mackey, Z.B.; Motycka, T.A. Completion of base excision repair by mammalian DNA ligases. Prog. Nucleic Acid Res. Mol. Biol. 2001, 68, 151-164.

81. Simsek, D.; Furda, A.; Gao, Y.; Artus, J.; Brunet, E.; Hadjantonakis, A.K.; van Houten, B.; Shuman, S.; McKinnon, P.J.; Jasin, M. Crucial role for DNA ligase III in mitochondria but not in XRCC1-dependent repair. Nature 2011, 471, 245-248.

82. Montecucco, A.; Biamonti, G.; Savini, E.; Focher, F.; Spadari, S.; Ciarrocchi, G. DNA ligase I gene expression during differentiation and cell proliferation. Nucleic Acids Res. 1992, 20, 6209-6214.

83. Dou, H.; Theriot, C.A.; Das, A.; Hegde, M.L.; Matsumoto, Y.; Boldogh, I.; Hazra, T.K.; Bhakat, K.K.; Mitra, S. Interaction of the human DNA glycosylase NEIL1 with proliferating cell nuclear antigen. The potential for replication-associated repair of oxidized bases in mammalian genomes. J. Biol. Chem. 2008, 283, 3130-3140.

84. Yang, S.W.; Burgin, A.B., Jr.; Huizenga, B.N.; Robertson, C.A.; Yao, K.C.; Nash, H.A. A eukaryotic enzyme that can disjoin dead-end covalent complexes between DNA and type I topoisomerases. Proc. Natl. Acad. Sci. USA 1996, 93, 11534-11539.

85. Pouliot, J.J.; Yao, K.C.; Robertson, C.A.; Nash, H.A. Yeast gene for a Tyr-DNA phosphodiesterase that repairs topoisomerase I complexes. Science 1999, 286, 552-555.

86. El-Khamisy, S.F.; Saifi, G.M.; Weinfeld, M.; Johansson, F.; Helleday, T.; Lupski, J.R.; Caldecott, K.W. Defective DNA single-strand break repair in spinocerebellar ataxia with axonal neuropathy-1. Nature 2005, 434, 108-113.

87. Ahel, I.; Rass, U.; El-Khamisy, S.F.; Katyal, S.; Clements, P.M.; McKinnon, P.J.; Caldecott, K.W.; West, S.C. The neurodegenerative disease protein aprataxin resolves abortive DNA ligation intermediates. Nature 2006, 443, 713-716.

88. Rass, U.; Ahel, I.; West, S.C. Actions of aprataxin in multiple DNA repair pathways. J. Biol. Chem. 2007, 282, 9469-9474.

89. Banerjee, D.; Mandal, S.M.; Das, A.; Hegde, M.L.; Das, S.; Bhakat, K.K.; Boldogh, I.; Sarkar, P.S.; Mitra, S.; Hazra, T.K. Preferential repair of oxidized base damage in the transcribed genes of mammalian cells. J. Biol. Chem. 2011, 286, 6006-6016.

90. Schreiber, V.; Dantzer, F.; Ame, J.C.; de Murcia, G. Poly(ADP-ribose): Novel functions for an old molecule. Nat. Rev. Mol. Cell Biol. 2006, 7, 517-528.

91. Caldecott, K.W. Single-strand break repair and genetic disease. Nat. Rev. Genet. 2008, 9, 619-631. 
92. Dianova, I.I.; Sleeth, K.M.; Allinson, S.L.; Parsons, J.L.; Breslin, C.; Caldecott, K.W.; Dianov, G.L. XRCC1-DNA polymerase beta interaction is required for efficient base excision repair. Nucleic Acids Res. 2004, 32, 2550-2555.

93. El-Khamisy, S.F.; Hartsuiker, E.; Caldecott, K.W. TDP1 facilitates repair of ionizing radiation-induced DNA single-strand breaks. DNA Repair 2007, 6, 1485-1495.

94. Vidal, A.E.; Boiteux, S.; Hickson, I.D.; Radicella, J.P. XRCC1 coordinates the initial and late stages of DNA abasic site repair through protein-protein interactions. EMBO J. 2001, 20, 6530-6539.

95. Chattopadhyay, R.; Das, S.; Maiti, A.K.; Boldogh, I.; Xie, J.; Hazra, T.K.; Kohno, K.; Mitra, S.; Bhakat, K.K. Regulatory role of human AP-endonuclease (APE1/Ref-1) in YB-1-mediated activation of the multidrug resistance gene MDR1. Mol. Cell. Biol. 2008, 28, 7066-7080.

96. Marenstein, D.R.; Ocampo, M.T.; Chan, M.K.; Altamirano, A.; Basu, A.K.; Boorstein, R.J.; Cunningham, R.P.; Teebor, G.W. Stimulation of human endonuclease III by Y box-binding protein 1 (DNA-binding protein $\beta$ ). Interaction between a base excision repair enzyme and a transcription factor. J. Biol. Chem. 2001, 276, 21242-21249.

97. Hegde, M.L.; Banerjee, S.; Hegde, P.M.; Bellot, L.J.; Hazra, T.K.; Boldogh, I.; Mitra, S. Enhancement of NEIL1 protein-initiated oxidized DNA base excision repair by heterogeneous nuclear ribonucleoprotein U (hnRNP-U) via direct interaction. J. Biol. Chem. 2012, 287, 34202-34211.

98. Bhakat, K.K.; Hazra, T.K.; Mitra, S. Acetylation of the human DNA glycosylase NEIL2 and inhibition of its activity. Nucleic Acids Res. 2004, 32, 3033-3039.

99. Bhakat, K.K.; Mokkapati, S.K.; Boldogh, I.; Hazra, T.K.; Mitra, S. Acetylation of human 8-oxoguanine-DNA glycosylase by p300 and its role in 8-oxoguanine repair in vivo. Mol. Cell. Biol. 2006, 26, 1654-1665.

100. Sengupta, S.; Mantha, A.K.; Mitra, S.; Bhakat, K.K. Human AP endonuclease (APE1/Ref-1) and its acetylation regulate YB-1-p300 recruitment and RNA polymerase II loading in the drug-induced activation of multidrug resistance gene MDR1. Oncogene 2010, 30, 482-493.

101. Tini, M.; Benecke, A.; Um, S.J.; Torchia, J.; Evans, R.M.; Chambon, P. Association of CBP/p300 acetylase and thymine DNA glycosylase links DNA repair and transcription. Mol. Cell 2002, 9, 265-277.

102. Yacoub, A.; Kelley, M.R.; Deutsch, W.A. The DNA repair activity of human redox/repair protein APE/Ref-1 is inactivated by phosphorylation. Cancer Res. 1997, 57, 5457-5459.

103. Fritz, G.; Kaina, B. Phosphorylation of the DNA repair protein APE/Ref-1 by CKII affects redox regulation of AP-1. Oncogene 1999, 18, 1033-1040.

104. Huang, E.; Qu, D.; Zhang, Y.; Venderova, K.; Haque, M.E.; Rousseaux, M.W.; Slack, R.S.; Woulfe, J.M.; Park, D.S. The role of CDK5-mediated apurinic/apyrimidinic endonuclease 1 phosphorylation in neuronal death. Nat. Cell Biol. 2010, 12, 563-571.

105. Parsons, J.L.; Tait, P.S.; Finch, D.; Dianova, I.I.; Edelmann, M.J.; Khoronenkova, S.V.; Kessler, B.M.; Sharma, R.A.; McKenna, W.G.; Dianov, G.L. Ubiquitin ligase ARF-BP1/mule modulates base excision repair. EMBO J. 2009, 28, 3207-3215. 
106. Parsons, J.L.; Dianova, I.I.; Finch, D.; Tait, P.S.; Strom, C.E.; Helleday, T.; Dianov, G.L. XRCC1 phosphorylation by $\mathrm{CK} 2$ is required for its stability and efficient DNA repair. DNA Repair 2010, 9, 835-841.

107. Wang, T.; Simbulan-Rosenthal, C.M.; Smulson, M.E.; Chock, P.B.; Yang, D.C. Polyubiquitylation of PARP-1 through ubiquitin $\mathrm{K} 48$ is modulated by activated DNA, NAD ${ }^{+}$, and dipeptides. J. Cell. Biochem. 2008, 104, 318-328.

108. Takahashi, H.; Hatakeyama, S.; Saitoh, H.; Nakayama, K.I. Noncovalent SUMO-1 binding activity of thymine DNA glycosylase (TDG) is required for its SUMO-1 modification and colocalization with the promyelocytic leukemia protein. J. Biol. Chem. 2005, 280, 5611-5621.

109. Hardeland, U.; Steinacher, R.; Jiricny, J.; Schar, P. Modification of the human thymine-DNA glycosylase by ubiquitin-like proteins facilitates enzymatic turnover. EMBO J. 2002, 21, 1456-1464.

110. Steinacher, R.; Schar, P. Functionality of human thymine DNA glycosylase requires SUMO-regulated changes in protein conformation. Curr. Biol. 2005, 15, 616-623.

111. El-Andaloussi, N.; Valovka, T.; Toueille, M.; Hassa, P.O.; Gehrig, P.; Covic, M.; Hubscher, U.; Hottiger, M.O. Methylation of DNA polymerase beta by protein arginine methyltransferase 1 regulates its binding to proliferating cell nuclear antigen. FASEB J. 2007, 21, 26-34.

112. Kedar, P.S.; Kim, S.J.; Robertson, A.; Hou, E.; Prasad, R.; Horton, J.K.; Wilson, S.H. Direct interaction between mammalian DNA polymerase beta and proliferating cell nuclear antigen. J. Biol. Chem. 2002, 277, 31115-31123.

113. Hakme, A.; Wong, H.K.; Dantzer, F.; Schreiber, V. The expanding field of poly(ADP-ribosyl)ation reactions. "Protein modifications: Beyond the usual suspects" review series. EMBO Rep. 2008, 9 , 1094-1100.

114. El-Khamisy, S.F.; Masutani, M.; Suzuki, H.; Caldecott, K.W. A requirement for PARP-1 for the assembly or stability of XRCC1 nuclear foci at sites of oxidative DNA damage. Nucleic Acids Res. 2003, 31, 5526-5533.

115. Huang, J.Y.; Chen, W.H.; Chang, Y.L.; Wang, H.T.; Chuang, W.T.; Lee, S.C. Modulation of nucleosome-binding activity of fact by poly(ADP-ribosyl)ation. Nucleic Acids Res. 2006, 34, 2398-2407.

116. Chang, D.Y.; Shi, G.; Durand-Dubief, M.; Ekwall, K.; Lu, A.L. The role of MutY homolog (Myh1) in controlling the histone deacetylase Hst4 in the fission yeast Schizosaccharomyces pombe. J. Mol. Biol. 2011, 405, 653-665.

117. Hegde, M.L.; Izumi, T.; Mitra, S. Oxidized base damage and single-strand break repair in mammalian genomes: Role of disordered regions and posttranslational modifications in early enzymes. Prog. Mol. Biol. Transl. Sci. 2012, 110, 123-153.

118. Hegde, M.L.; Hazra, T.K.; Mitra, S. Functions of disordered regions in mammalian early base excision repair proteins. Cell. Mol. Life Sci. 2010, 67, 3573-3587.

119. Haynes, C.; Oldfield, C.J.; Ji, F.; Klitgord, N.; Cusick, M.E.; Radivojac, P.; Uversky, V.N.; Vidal, M.; Iakoucheva, L.M. Intrinsic disorder is a common feature of hub proteins from four eukaryotic interactomes. PLoS Comput. Biol. 2006, 2, e100.

120. Pesole, G.; Gissi, C.; de Chirico, A.; Saccone, C. Nucleotide substitution rate of mammalian mitochondrial genomes. J. Mol. Evol. 1999, 48, 427-434. 
121. Yakes, F.M.; van Houten, B. Mitochondrial DNA damage is more extensive and persists longer than nuclear DNA damage in human cells following oxidative stress. Proc. Natl. Acad. Sci. USA 1997, 94, 514-519.

122. Caldecott, K.W.; McKeown, C.K.; Tucker, J.D.; Ljungquist, S.; Thompson, L.H. An interaction between the mammalian DNA repair protein XRCC1 and DNA ligase III. Mol. Cell. Biol. 1994, 14, 68-76.

123. Szczesny, B.; Tann, A.W.; Longley, M.J.; Copeland, W.C.; Mitra, S. Long patch base excision repair in mammalian mitochondrial genomes. J. Biol. Chem. 2008, 283, 26349-26356.

124. Wunderlich, V.; Tetzlaff, I.; Graffi, A. Studies on nitrosodimethylamine: Preferential methylation of mitochondrial DNA in rats and hamsters. Chem. Biol. Interact. 1972, 4, 81-89.

125. Gavin, C.E.; Gunter, K.K.; Gunter, T.E. $\mathrm{Mn}^{2+}$ sequestration by mitochondria and inhibition of oxidative phosphorylation. Toxicol. Appl. Pharmacol. 1992, 115, 1-5.

126. Johnson, F.O.; Atchison, W.D. The role of environmental mercury, lead and pesticide exposure in development of amyotrophic lateral sclerosis. Neurotoxicology 2009, 30, 761-765.

127. Sokolova, I.M.; Ringwood, A.H.; Johnson, C. Tissue-specific accumulation of cadmium in subcellular compartments of eastern oysters Crassostrea virginica Gmelin (Bivalvia: Ostreidae). Aquat. Toxicol. 2005, 74, 218-228.

128. Karahalil, B.; Hogue, B.A.; de Souza-Pinto, N.C.; Bohr, V.A. Base excision repair capacity in mitochondria and nuclei: Tissue-specific variations. FASEB J. 2002, 16, 1895-1902.

129. Szczesny, B.; Tann, A.W.; Mitra, S. Age- and tissue-specific changes in mitochondrial and nuclear DNA base excision repair activity in mice: Susceptibility of skeletal muscles to oxidative injury. Mech. Ageing Dev. 2010, 131, 330-337.

130. Englander, E.W. Brain capacity for repair of oxidatively damaged DNA and preservation of neuronal function. Mech. Ageing Dev. 2008, 129, 475-482.

131. Raffoul, J.J.; Cabelof, D.C.; Nakamura, J.; Meira, L.B.; Friedberg, E.C.; Heydari, A.R. Apurinic/apyrimidinic endonuclease (APE/Ref-1) haploinsufficient mice display tissue-specific differences in DNA polymerase beta-dependent base excision repair. J. Biol. Chem. 2004, 279, 18425-18433.

132. Canugovi, C.; Yoon, J.S.; Feldman, N.H.; Croteau, D.L.; Mattson, M.P.; Bohr, V.A. Endonuclease VIII-like 1 (NEIL1) promotes short-term spatial memory retention and protects from ischemic stroke-induced brain dysfunction and death in mice. Proc. Natl. Acad. Sci. USA 2012, 109, 14948-14953.

133. Torisu, K.; Tsuchimoto, D.; Ohnishi, Y.; Nakabeppu, Y. Hematopoietic tissue-specific expression of mouse NEIL3 for endonuclease VIII-like protein. J. Biochem. 2005, 138, 763-772.

134. Hildrestrand, G.A.; Neurauter, C.G.; Diep, D.B.; Castellanos, C.G.; Krauss, S.; Bjoras, M.; Luna, L. Expression patterns of NEIL3 during embryonic brain development and neoplasia. BMC Neurosci. 2009, doi:10.1186/1471-2202-10-45.

135. Regnell, C.E.; Hildrestrand, G.A.; Sejersted, Y.; Medin, T.; Moldestad, O.; Rolseth, V.; Krokeide, S.Z.; Suganthan, R.; Luna, L.; Bjoras, M.; et al. Hippocampal adult neurogenesis is maintained by NEIL3-dependent repair of oxidative DNA lesions in neural progenitor cells. Cell Rep. 2012, 2, 503-510. 
136. Rolseth, V.; Krokeide, S.Z.; Kunke, D.; Neurauter, C.G.; Suganthan, R.; Sejersted, Y.; Hildrestrand, G.A.; Bjoras, M.; Luna, L. Loss of NEIL3, the major DNA glycosylase activity for removal of hydantoins in single stranded DNA, reduces cellular proliferation and sensitizes cells to genotoxic stress. Biochim. Biophys. Acta 2013, 1833, 1157-1164.

137. Uhlen, M.; Oksvold, P.; Fagerberg, L.; Lundberg, E.; Jonasson, K.; Forsberg, M.; Zwahlen, M.; Kampf, C.; Wester, K.; Hober, S.; et al. Towards a knowledge-based human protein atlas. Nat. Biotechnol. 2010, 28, 1248-1250.

138. Swain, U.; Subba Rao, K. Study of DNA damage via the comet assay and base excision repair activities in rat brain neurons and astrocytes during aging. Mech. Ageing Dev. 2011, 132, 374-381.

139. Fukae, J.; Mizuno, Y.; Hattori, N. Mitochondrial dysfunction in Parkinson's disease. Mitochondrion 2007, 7, 58-62.

140. Sheng, Z.; Oka, S.; Tsuchimoto, D.; Abolhassani, N.; Nomaru, H.; Sakumi, K.; Yamada, H.; Nakabeppu, Y. 8-oxoguanine causes neurodegeneration during mutyh-mediated DNA base excision repair. J. Clin. Investig. 2012, 122, 4344-4361.

141. Jiang, Y.; Guo, C.; Fishel, M.L.; Wang, Z.Y.; Vasko, M.R.; Kelley, M.R. Role of APE1 in differentiated neuroblastoma SH-SY5Y cells in response to oxidative stress: Use of APE1 small molecule inhibitors to delineate APE1 functions. DNA Repair 2009, 8, 1273-1282.

142. Vasko, M.R.; Guo, C.; Kelley, M.R. The multifunctional DNA repair/redox enzyme APE1/Ref-1 promotes survival of neurons after oxidative stress. DNA Repair 2005, 4, 367-379.

143. Jiang, Y.; Guo, C.; Vasko, M.R.; Kelley, M.R. Implications of apurinic/apyrimidinic endonuclease in reactive oxygen signaling response after cisplatin treatment of dorsal root ganglion neurons. Cancer Res. 2008, 68, 6425-6434.

144. Breslin, C.; Caldecott, K.W. DNA 3'-phosphatase activity is critical for rapid global rates of single-strand break repair following oxidative stress. Mol. Cell. Biol. 2009, 29, 4653-4662.

145. Wilson, S.H. Mammalian base excision repair and DNA polymerase beta. Mutat. Res. 1998, 407, 203-215.

146. Wilson, D.M., 3rd; McNeill, D.R. Base excision repair and the central nervous system. Neuroscience 2007, 145, 1187-1200.

147. Akbari, M.; Pena-Diaz, J.; Andersen, S.; Liabakk, N.B.; Otterlei, M.; Krokan, H.E. Extracts of proliferating and non-proliferating human cells display different base excision pathways and repair fidelity. DNA Repair 2009, 8, 834-843.

148. Wei, W.; Englander, E.W. DNA polymerase beta-catalyzed-PCNA independent long patch base excision repair synthesis: A mechanism for repair of oxidatively damaged DNA ends in post-mitotic brain. J. Neurochem. 2008, 107, 734-744.

149. Kenche, V.B.; Barnham, K.J. Alzheimer's disease \& metals: Therapeutic opportunities. Br. J. Pharmacol. 2011, 163, 211-219.

150. Raven, E.P.; Lu, P.H.; Tishler, T.A.; Heydari, P.; Bartzokis, G. Increased iron levels and decreased tissue integrity in hippocampus of Alzheimer's disease detected in vivo with magnetic resonance imaging. J. Alzheimers Dis. 2013, 37, 127-136. 
151. Lee, H.P.; Zhu, X.; Liu, G.; Chen, S.G.; Perry, G.; Smith, M.A.; Lee, H.G. Divalent metal transporter, iron, and Parkinson's disease: A pathological relationship. Cell Res. 2010, 20, 397-399.

152. Pamphlett, R.; Kum Jew, S. Heavy metals in locus ceruleus and motor neurons in motor neuron disease. Acta Neuropathol. Commun. 2013, doi:10.1186/2051-5960-1-81.

153. Barbeito, A.G.; Levade, T.; Delisle, M.B.; Ghetti, B.; Vidal, R. Abnormal iron metabolism in fibroblasts from a patient with the neurodegenerative disease hereditary ferritinopathy. Mol. Neurodegener. 2010, doi:10.1186/1750-1326-5-50.

154. Texel, S.J.; Xu, X.; Harris, Z.L. Ceruloplasmin in neurodegenerative diseases. Biochem. Soc. Trans. 2008, 36, 1277-1281.

155. Koeppen, A.H. A brief history of brain iron research. J. Neurol. Sci. 2003, 207, 95-97.

156. Rao, G.N.; Ney, E.; Herbert, R.A. Changes associated with delay of mammary cancer by retinoid analogues in transgenic mice bearing c-neu oncogene. Breast Cancer Res. Treat. 1999, $58,241-254$.

157. Molina-Holgado, F.; Hider, R.C.; Gaeta, A.; Williams, R.; Francis, P. Metals ions and neurodegeneration. Biometals 2007, 20, 639-654.

158. Huang, X.; Atwood, C.S.; Moir, R.D.; Hartshorn, M.A.; Vonsattel, J.P.; Tanzi, R.E.; Bush, A.I. Zinc-induced Alzheimer's Abeta1-40 aggregation is mediated by conformational factors. J. Biol. Chem. 1997, 272, 26464-26470.

159. Youdim, M.B.; Ben-Shachar, D.; Riederer, P. Iron in brain function and dysfunction with emphasis on Parkinson's disease. Eur. Neurol. 1991, 31, 34-40.

160. Bowman, A.B.; Kwakye, G.F.; Herrero Hernandez, E.; Aschner, M. Role of manganese in neurodegenerative diseases. J. Trace Elem. Med. Biol. 2011, 25, 191-203.

161. Shaw, C.A.; Tomljenovic, L. Aluminum in the central nervous system (CNS): Toxicity in humans and animals, vaccine adjuvants, and autoimmunity. Immunol. Res. 2013, 56, 304-316.

162. Walton, N.M.; Shin, R.; Tajinda, K.; Heusner, C.L.; Kogan, J.H.; Miyake, S.; Chen, Q.; Tamura, K.; Matsumoto, M. Adult neurogenesis transiently generates oxidative stress. PLoS One 2012, 7, e35264.

163. Zatta, P. Biological models for the study of aluminum neurotoxicity. Acta Med. Romana 1997, 35, 592-600.

164. Rao, K.S.; Hegde, M.L.; Anitha, S.; Musicco, M.; Zucca, F.A.; Turro, N.J.; Zecca, L. Amyloid beta and neuromelanin-Toxic or protective molecules? The cellular context makes the difference. Prog. Neurobiol. 2006, 78, 364-373.

165. Wright, R.O.; Tsaih, S.W.; Schwartz, J.; Spiro, A., 3rd; McDonald, K.; Weiss, S.T.; Hu, H. Lead exposure biomarkers and mini-mental status exam scores in older men. Epidemiology 2003, 14, 713-718.

166. Tavakoli-Nezhad, M.; Barron, A.J.; Pitts, D.K. Postnatal inorganic lead exposure decreases the number of spontaneously active midbrain dopamine neurons in the rat. Neurotoxicology 2001, 22, 259-269.

167. Basha, M.R.; Murali, M.; Siddiqi, H.K.; Ghosal, K.; Siddiqi, O.K.; Lashuel, H.A.; Ge, Y.W.; Lahiri, D.K.; Zawia, N.H. Lead (PB) exposure and its effect on APP proteolysis and Abeta aggregation. FASEB J. 2005, 19, 2083-2084. 
168. Wu, J.; Basha, M.R.; Brock, B.; Cox, D.P.; Cardozo-Pelaez, F.; McPherson, C.A.; Harry, J.; Rice, D.C.; Maloney, B.; Chen, D.; et al. Alzheimer's disease (AD)-like pathology in aged monkeys after infantile exposure to environmental metal lead (PB): Evidence for a developmental origin and environmental link for AD. J. Neurosci. 2008, 28, 3-9.

169. Bourdineaud, J.P.; Fujimura, M.; Laclau, M.; Sawada, M.; Yasutake, A. Deleterious effects in mice of fish-associated methylmercury contained in a diet mimicking the western populations' average fish consumption. Environ. Int. 2011, 37, 303-313.

170. Yee, S.; Choi, B.H. Oxidative stress in neurotoxic effects of methylmercury poisoning. Neurotoxicology 1996, 17, 17-26.

171. Hegde, M.L.; Anitha, S.; Latha, K.S.; Mustak, M.S.; Stein, R.; Ravid, R.; Rao, K.S. First evidence for helical transitions in supercoiled DNA by amyloid beta peptide (1-42) and aluminum: A new insight in understanding Alzheimer's disease. J. Mol. Neurosci. 2004, 22, 19-31.

172. Rao, K.S.J.; Rao, R.V.; Shanmugavelu, P.; Menon, R.B. Trace elements in Alzheimer's disease brain: A new hypothesis. Alzheimers Rep. 1999, 2, 241-246.

173. Pande, M.B.; Nagabhushan, P.; Hegde, M.L.; Rao, T.S.; Rao, K.S. An algorithmic approach to understand trace elemental homeostasis in serum samples of parkinson disease. Comput. Biol. Med. 2005, 35, 475-493.

174. Pfaender, S.; Grabrucker, A.M. Characterization of biometal profiles in neurological disorders. Metallomics 2014, 6, 960-977.

175. Hegde, M.L.; Hegde, P.M.; Rao, K.S.; Mitra, S. Oxidative genome damage and its repair in neurodegenerative diseases: Function of transition metals as a double-edged sword. J. Alzheimers Dis. 2011, 24, 183-198.

176. Robison, S.H.; Cantoni, O.; Costa, M. Analysis of metal-induced DNA lesions and DNA-repair replication in mammalian cells. Mutat. Res. 1984, 131, 173-181.

177. Giles, N.M.; Watts, A.B.; Giles, G.I.; Fry, F.H.; Littlechild, J.A.; Jacob, C. Metal and redox modulation of cysteine protein function. Chem. Biol. 2003, 10, 677-693.

178. Himmelfarb, J.; McMonagle, E.; McMenamin, E. Plasma protein thiol oxidation and carbonyl formation in chronic renal failure. Kidney Int. 2000, 58, 2571-2578.

179. Hegde, M.L.; Gupta, V.B.; Anitha, M.; Harikrishna, T.; Shankar, S.K.; Muthane, U.; Subba Rao, K.; Jagannatha Rao, K.S. Studies on genomic DNA topology and stability in brain regions of Parkinson's disease. Arch. Biochem. Biophys. 2006, 449, 143-156.

180. Jeppesen, D.K.; Bohr, V.A.; Stevnsner, T. DNA repair deficiency in neurodegeneration. Prog. Neurobiol. 2011, 94, 166-200.

181. Rass, U.; Ahel, I.; West, S.C. Defective DNA repair and neurodegenerative disease. Cell 2007, 130, 991-1004.

182. Maynard, S.; Schurman, S.H.; Harboe, C.; de Souza-Pinto, N.C.; Bohr, V.A. Base excision repair of oxidative DNA damage and association with cancer and aging. Carcinogenesis 2009, 30, 2-10.

183. Gredilla, R.; Garm, C.; Stevnsner, T. Nuclear and mitochondrial DNA repair in selected eukaryotic aging model systems. Oxid. Med. Cell. Longev. 2012, doi:10.1155/2012/282438.

184. Hartwig, A. Role of DNA repair inhibition in lead- and cadmium-induced genotoxicity: A review. Environ. Health Perspect. 1994, 102, 45-50. 
185. Hengstler, J.G.; Bolm-Audorff, U.; Faldum, A.; Janssen, K.; Reifenrath, M.; Gotte, W.; Jung, D.; Mayer-Popken, O.; Fuchs, J.; Gebhard, S.; et al. Occupational exposure to heavy metals: DNA damage induction and DNA repair inhibition prove co-exposures to cadmium, cobalt and lead as more dangerous than hitherto expected. Carcinogenesis 2003, 24, 63-73.

186. Adhikari, S.; Toretsky, J.A.; Yuan, L.; Roy, R. Magnesium, essential for base excision repair enzymes, inhibits substrate binding of N-methylpurine-DNA glycosylase. J. Biol. Chem. 2006, 281, 29525-29532.

187. Wang, P.; Guliaev, A.B.; Hang, B. Metal inhibition of human n-methylpurine-DNA glycosylase activity in base excision repair. Toxicol. Lett. 2006, 166, 237-247.

188. Whiteside, J.R.; Box, C.L.; McMillan, T.J.; Allinson, S.L. Cadmium and copper inhibit both DNA repair activities of polynucleotide kinase. DNA Repair 2010, 9, 83-89.

189. McNeill, D.R.; Narayana, A.; Wong, H.K.; Wilson, D.M., 3rd. Inhibition of APE1 nuclease activity by lead, iron, and cadmium. Environ. Health Perspect. 2004, 112, 799-804.

190. Hegde, M.L.; Jagannatha Rao, K.S. Challenges and complexities of alpha-synuclein toxicity: New postulates in unfolding the mystery associated with Parkinson's disease. Arch. Biochem. Biophys. 2003, 418, 169-178.

191. Hegde, M.L. Molecular characterization of neuroprotective activities of plant based products could revive their utilization and lead discovery of new drug candidates for brain diseases. J. Pharm. Bioallied Sci. 2014, 6, 63-64.

192. Romero, A.; Ramos, E.; de Los Rios, C.; Egea, J.; del Pino, J.; Reiter, R.J. A review of metal-catalyzed molecular damage: Protection by melatonin. J. Pineal Res. 2014, 56, 343-370.

(C) 2014 by the authors; licensee MDPI, Basel, Switzerland. This article is an open access article distributed under the terms and conditions of the Creative Commons Attribution license (http://creativecommons.org/licenses/by/3.0/). 